\title{
Efifects of reducing the use of soyabean oil-meal with or without lysine in growing-finishing pig diets based on maize or wheat
}

\author{
J. CASTAING and M. LEUILLET* \\ Association Générale des Producteurs de Mais, \\ 64000 Pau \\ * Institut technique des Céréales et des Fourrages, \\ 8, Avenue du Président Wilson, \\ 75016 Paris
}

Reduction in the use of soyabean oil-meal in cereal based diets (maize and wheat) was made in the following way :

-- by decreasing the dietary crude protein level during the finishing period (60- $103 \mathrm{~kg}$ )

- by L-lysine supplementation of diets with a low crude protein content during the growingfinishing period or the finishing periort.

\section{Maize}

For castrated males, a protein level of 18 p. I 00 till $60 \mathrm{~kg}$ live weight followed by $44 \mathrm{p}$. Ioo till slaughter resulted in the highest growth performances and the best feed conversion ratios.

For females, there was no significant difference between the results obtained with the following allowances :

- I 8 p. Ioo crude protein till $60 \mathrm{~kg}$ live weight - I6 p. roo crude protein from $60-103 \mathrm{~kg}$ live weight ;

- I8 p. Ioo crude protein till $60 \mathrm{~kg}$ live weight - I 4 p. Ioo crude protein + lysine supplementation (0.20 p. I00) from 60-103 kg live weight;

- I 4 p. Ioo crude protein + lysine supplementation during the whole growing-finishing period $(0.40 \mathrm{p}$. Ioo till $60 \mathrm{~kg}$ and $0.20 \mathrm{p}$. Ioo from 60 to $103 \mathrm{~kg})$.

\section{Wheat}

For the two sexes, the best performances were obtained with the following allowances :

I.- 7.5 p. roo crude protein during the growing-finishing period,

- 17.5 p. Ioo crude protein till $60 \mathrm{~kg}$ live weight,

- I6.7 p. I oo crude protein from 60 to $103 \mathrm{~kg}$ live weight.

Lysine supplementation applied during the finishing period or during the whole growingfinishing period to a basal diet containing I 4 p. Ioo crude protein did not lead to the same performances as the diets containing 17.5 and $16.7 \mathrm{p}$. Ioo crude protein and this raises the question of the involvement of other limiting factors. 